\title{
Epidemiological and viral features of a cohort of SARS-CoV-2 symptomatic and asymptomatic individuals in an area of the Colombian Caribbean
}

\author{
Salim Mattar ${ }^{* *}$, Caty Martinez-Bravo ${ }^{1}$, Ricardo Rivero ${ }^{1}$, Héctor Contreras ${ }^{1}$, Álvaro A. Faccini-Martínez²,

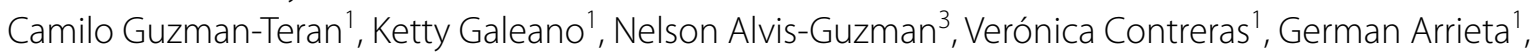 \\ Marco Gonzalez-Tous', Jorge Miranda', Martha Ospina ${ }^{4}$, Francisco Camargo-Assis ${ }^{5}$, Marcela Mercado-Reyes ${ }^{4}$, \\ Evelyn Garay ${ }^{1}$, Alejandra Garcia-Perez ${ }^{1}$, Yesica Lopez ${ }^{1}$ and Vaneza Tique
}

\begin{abstract}
Background: Severe acute respiratory syndrome Coronavirus 2 (SARS-CoV-2) is an emerging viral pandemic disease. In the last 6 months, SARS-CoV-2 has caused millions of reported cases and hundreds of thousands of deaths. As other world regions, South America has not contained the pandemic's advance since it lacks the hospital and economic capacities. Public health implications of transmission, while the asymptomatic/presymptomatic infection is a critical concern at the current pandemic.
\end{abstract}

Objective: Describe the socio-demographic, clinical, and viral features of a cohort of SARS-CoV-2 infected individuals from the Colombian Caribbean.

Methods: Six hundred eighty-six clinical samples of suspected SARS-CoV-2 infection cases and contacts individuals from several hospital centers in the department of Córdoba, Colombia, were received at our laboratory between April 9th and May 16th, 2020. RNA was extracted using lysis buffers and spin columns. The samples were tested for SARSCoV-2 by reverse transcription real-time polymerase chain reaction (RT-qPCR) using commercially available multiplex real-time PCR assay for simultaneous detection of 3 target genes of SARS-CoV-2 (Allplex ${ }^{\mathrm{TM}}$, 2019-nCoV assay, Korea). Viral copies quantification was done using a standard curve constructed from seriated dilutions of a SARS-CoV-2 positive control. Statics descriptive methods were used.

Results: Thirty-five nasopharyngeal samples were positive for SARS-CoV-2 infection; the average age was 43 (range, 1-95 years). Seventeen of 35 (49\%) of the patients showed symptoms. Most of them had a cough, fever, and odynophagia; three of the patients reported having arthralgia. Only two patients required hospitalization. None of the patients had known co-morbidities. RT-qPCR results show that two of the symptomatic patients had significantly higher RNA copies than the rest. Eighteen of 35 (51\%) individuals were asymptomatic, and the average age was 30

\footnotetext{
*Correspondence: mattarsalim@hotmail.com; smattar@correo.unicordoba. edu.co

${ }^{1}$ Instituto de Investigaciones Biológicas del Trópico, Facultad de Medicina Veterinaria y Zootecnia, Universidad de Córdoba, Montería, Colombia

Full list of author information is available at the end of the article
}

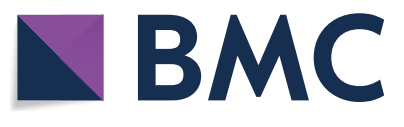

(c) The Author(s) 2020. This article is licensed under a Creative Commons Attribution 4.0 International License, which permits use, sharing, adaptation, distribution and reproduction in any medium or format, as long as you give appropriate credit to the original author(s) and the source, provide a link to the Creative Commons licence, and indicate if changes were made. The images or other third party material in this article are included in the article's Creative Commons licence, unless indicated otherwise in a credit line to the material. If material is not included in the article's Creative Commons licence and your intended use is not permitted by statutory regulation or exceeds the permitted use, you will need to obtain permission directly from the copyright holder. To view a copy of this licence, visit http://creativeco mmons.org/licenses/by/4.0/. The Creative Commons Public Domain Dedication waiver (http://creativecommons.org/publicdomain/ zero/1.0/) applies to the data made available in this article, unless otherwise stated in a credit line to the data. 
(range, 6-61 years). Four asymptomatic individuals showed a higher copy than some symptomatic patients; nonetheless, the average of RNA copies $8.26 \times 10^{10}$ was lower than the symptomatic.

Conclusions: This study shows that asymptomatic patients may develop infections with a high number of RNA copies. Since a considerable percentage of infections may be asymptomatic/presymptomatic, enhanced testing approaches may be needed to detect these persons. Due the occurrence of a large proportion of infections being a result from transmission originated in asymptomatic/presymptomatic individuals, public health interventions in Colombia should be based on two steps: a massive molecular screening, and viral load quantification. Finally, a remarkable issue in our study is the average age of symptomatic and asymptomatic groups (43 and 30 respectively) which may be important because of the economic impact that has been caused by the coronavirus pandemic and may be probably the cause of the reduced lethality observed in the country and the department at the time of this study.

Keywords: Asymptomatic infections, COVID-19, Coronavirus infections, Pre symptomatic disease, Environment and public health, Communicable disease control

\section{Introduction}

Coronavirus disease 2019 (COVID-19), caused by Severe acute respiratory syndrome Coronavirus 2 (SARS-CoV-2), is an emerging viral disease that has caused millions of reported cases and hundreds of thousands of deaths in the last 6 months. As other world regions, nowadays, South America has not contained the pandemic's advance since it lacks the hospital and economic capacities, reporting more than nine million of infected people, being the top six countries' distribution as follows: Brazil has 5,224,362 cases, Argentina 979,119, Colombia 952,371, Peru 865,549, Chile 490,003, and Ecuador 152,422 cases [1]. Besides, the mortality per million people in Peru, Brazil, Bolivia, Chile, Ecuador, Argentina, and Colombia are 1.018, 722, 722, 709, 698, 576, and 564, respectively, with a total of 276,725 people who died $(99.25 \%$ of the total deaths in South America) [1]. In Colombia, the first case of SARS-CoV-2 infection was reported on March 6th, 2020, and has been shocked by the national incidence rate of $1,834.5$ cases per 100,000 inhabitants [2, $3]$. There have been 28,306 deaths from COVID-19 in the country, of which $64.2 \%$ correspond to men. $75.8 \%$ of the deceased are in the age group 60 and over [3]. The people with the highest number of deaths are between 70 and 79 years old, with 7321 , followed by the group between 60 and 69 years old, with 6542 deaths [3].

Cordoba department, in the Colombia Caribbean area, reported its first case on March 26th. On October 16th, $2.65 \%$ of cases did require hospitalization. However, the mortality rate reached $869.4 /$ million, higher than the national rate of $575.1 /$ million [2]. Implications in public health of pathogen transmission by patients with asymptomatic infections are a critical concern at the current pandemic $[5,9]$.
This study aims to describe the socio-demographic, clinical, and viral features of a cohort of SARS-CoV-2 infected individuals from the Colombian Caribbean.

\section{Methods}

Type of study, geographic localization, and sample collection

The present work is a prospective, descriptive study carried out in Cordoba, located in the northwest of Colombia; it is part of the Caribbean savanna (Fig. 1A). The mean annual temperature is $28{ }^{\circ} \mathrm{C}$, prevailing a dry and a rainy season. The department's population is $1,828,947$ inhabitants, and Monteria, Cordoba's capital city, has a population of 505,334 . This study was conducted at Instituto de Investigaciones Biológicas del Trópico, Universidad de Cordoba, which is licensed by Colombia's National Health Institute for the molecular diagnostic of SARS-CoV-2 human infection. Six hundred eightysix clinical samples of suspected SARS-CoV-2 infection cases and contacts individuals from several hospital centers in the province were received and processed by RTqPCR between April 9th and May 16th, 2020, with 35 positive results for SARS-CoV-2 infection. The ethical standards of the Ministry of Health of Colombia Resolution No. 8430 of 1993 were followed. The data of the present study correspond to patients coded under strict anonymity with an internal laboratory number.

\section{RNA extraction and SARS-CoV-2 detection}

Briefly, RNA was extracted using lysis buffers and spin columns. After RNA extraction, the samples were tested for SARS-CoV-2 by RT-qPCR using commercially available multiplex real-time PCR assay for simultaneous detection of 3 target genes of SARS-CoV-2 (AllplexTM, 2019-nCoV assay, Korea). The test is designed to detect RNA dependent RNA polymerase (RdRP), $\mathrm{N}$ genes specific for SARS-CoV-2, and $\mathrm{E}$ gene for all of 


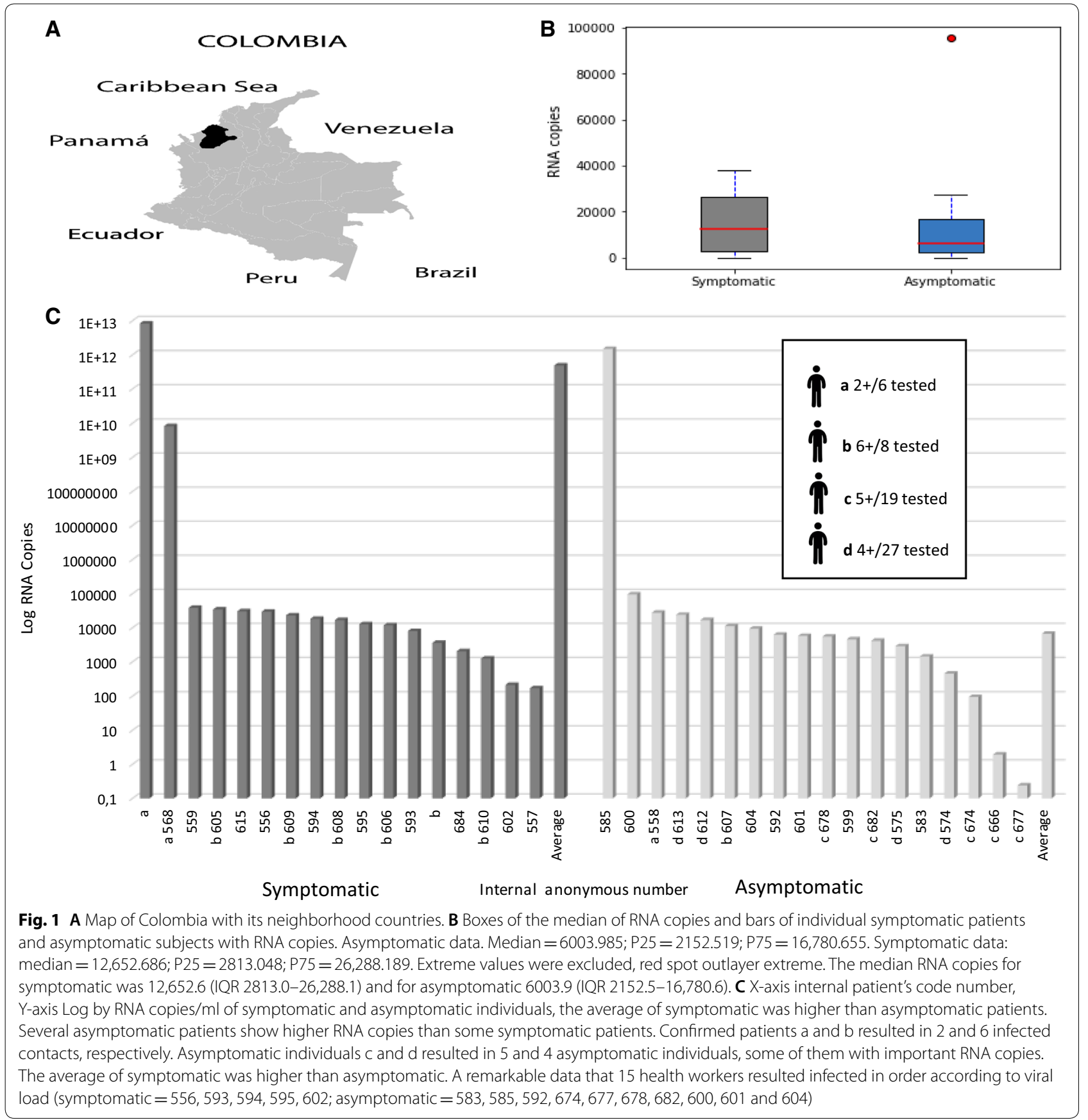

Sarbecoviruses, including SARS-CoV-2. Viral copies quantification was done using a standard curve constructed from seriated dilutions of a SARS-CoV-2 positive control. This control includes synthetic RNA target sequences for the three genes (RdRP, S, and N). According to the manufacturer instructions, samples tested with a $C t$ value $\leq 40$ were considered positive $[6,7]$. If a tested sample had a Ct between 40 and 45 , the test was repeated.

\section{Results and discussion}

Presently, the cases of asymptomatic/presymptomatic people represent the pandemic's significant problem due to its great spreading power of the coronavirus, which makes the control of the disease much more difficult. It is like fighting an invincible enemy; thus, it is vital to study healthy people. In that sense, while Colombia has tested 86,232 per million people in a country with 50 million people, Brazil, with 213 million people, has tested 84,035 
individuals, and Peru and Chile are the countries with more tested people in South America, exceeding both the 328,353 tests [1].

In the present study, $35 \%$ of nasopharyngeal samples were positive for SARS-CoV-2 infection. The average age was 43 (range, 1-95 years). Seventeen of 35 (49\%) of the patients showed symptoms, $9 / 17$ (53\%) of them were female, eight patients were from the urban area of Monteria (505,334 inhabitants), eight from Sahagun (107,636 inhabitants), and one from Cerete (105,815 inhabitants). Moreover, most of them showed cough, fever, and odynophagia; 3 of the patients reported having arthralgia
(Table 1). Only two patients required hospitalization. So far, all of the symptomatic patients are alive and have recovered from the infection. Both pediatric patients were symptomatic (Table 1). None of the patients had known co-morbidities. Only four symptomatic patients reported not having expositional contact with an infected person. RT-qPCR results show that two of the symptomatic patients (codes 505, 568) had significantly higher RNA copies than the rest of them. The average RNA copies were very high $4 \times 9^{11}$ (Table 1 ). Asymptomatic individuals 585, 600, 613, and 612 showed a higher number of RNA copies than some symptomatic patients

Table 1 Epidemiological, clinical, demographic information, and RNA virus copies

\begin{tabular}{|c|c|c|c|c|c|c|c|}
\hline $\begin{array}{l}\text { Anonymous } \\
\text { code }\end{array}$ & Date of sample & Symptomatic (onset date)/asymptomatic & Municipality & $\begin{array}{l}\text { Age/gender/ } \\
\text { health staff }\end{array}$ & Contact & $\mathrm{Ct}$ & RNA copies/ml \\
\hline $505 a$ & $9 / 05 / 2020$ & Symptomatic (30-Apr) Fe, Od & Sahagun & $65 / \mathrm{M} / \mathrm{no}$ & No & 24.00 & $8.33 \mathrm{E}+12$ \\
\hline 556 & $11 / 05 / 2020$ & Symptomatic (9-May) Co, Ar, Od & Sahagun & 32/F/yes & Yes & 36.94 & $2.96 \mathrm{E}+04$ \\
\hline 557 & $12 / 05 / 2020$ & Symptomatic (10-May) Fe, Ar, Od & Sahagun & $95 / \mathrm{M} / \mathrm{no}$ & No & 39.27 & $1.70 \mathrm{E}+02$ \\
\hline $568 \mathrm{a}$ & $12 / 05 / 2020$ & Symptomatic (9-May) Od & Sahagun & $52 / \mathrm{M} / \mathrm{no}$ & Yes & 24.03 & $8.26 \mathrm{E}+09$ \\
\hline 593 & $13 / 05 / 2020$ & Symptomatic (6-May) Co, Od & Sahagun & 28/F/yes & Yes & 38.64 & $7.97 \mathrm{E}+03$ \\
\hline 594 & $13 / 05 / 2020$ & Symptomatic (11-May) Co, Od & Sahagun & 31/F/yes & Yes & 37.42 & $1,82 \mathrm{E}+04$ \\
\hline 595 & $13 / 05 / 2020$ & Symptomatic (11-May) Co & Sahagun & 56/M/yes & Yes & 38.04 & $1.27 \mathrm{E}+04$ \\
\hline 615 & $13 / 05 / 2020$ & Symptomatic (10-May) Fe & Sahagun & 24/F/no & Yes & 36.91 & $3.05 E+04$ \\
\hline $517 b$ & $9 / 05 / 2020$ & Symptomatic (2-May) Co, Od & Monteria & 26/M/no & No & 37.12 & $3.59 E+03$ \\
\hline 602 & $12 / 05 / 2020$ & Symptomatic (10-May) Co, Od & Monteria & 41/F/yes & Yes & 40.37 & $2.15 E+02$ \\
\hline $605 b$ & $13 / 05 / 2020$ & Symptomatic (4-May) Co & Monteria & 23/F/no & Yes & 34.71 & $3.43 E+04$ \\
\hline $606 b$ & $13 / 05 / 2020$ & Symptomatic (10-May) Co & Monteria & $60 / \mathrm{M} / \mathrm{no}$ & Yes & 38.13 & $1.18 \mathrm{E}+04$ \\
\hline $608 b$ & $13 / 05 / 2020$ & Symptomatic (11-May) Co & Monteria & 43/F/no & Yes & 37.67 & $1.68 \mathrm{E}+04$ \\
\hline $609 b$ & $13 / 05 / 2020$ & Symptomatic (10-May) Od & Monteria & 1/M/no & Yes & 37.27 & $2.30 \mathrm{E}+04$ \\
\hline $610 b$ & $13 / 05 / 2020$ & Symptomatic (12-May) Fe & Monteria & 6/M/no & Yes & 41.18 & $1.24 \mathrm{E}+03$ \\
\hline 684 & $15 / 05 / 2020$ & Symptomatic (1-May) Ar & Monteria & 72/F/no & Yes & 37.75 & $2.04 \mathrm{E}+03$ \\
\hline 559 & $11 / 05 / 2020$ & Symptomatic (7-May) Od & Cerete & 74/F/no & No & 36.62 & $3.82 \mathrm{E}+04$ \\
\hline $558 a$ & $11 / 05 / 2020$ & Asymptomatic & Sahagun & 46/F/no & Yes & 36.62 & $2.76 \mathrm{E}+04$ \\
\hline 583 & $13 / 05 / 2020$ & Asymptomatic & Sahagun & 32/F/yes & Yes & 37.63 & $1.43 \mathrm{E}+03$ \\
\hline 585 & $13 / 05 / 2020$ & Asymptomatic & Sahagun & 30/F/yes & Yes & 24.84 & $1.49 \mathrm{E}+12$ \\
\hline 592 & 13/05/2020 & Asymptomatic & Sahagun & 21/M/yes & Yes & 38.96 & $6.26 \mathrm{E}+03$ \\
\hline $666 c$ & $15 / 05 / 2020$ & Asymptomatic & Sahagun & 34/F/no & Yes & 42.94 & $1.93 \mathrm{E}+00$ \\
\hline $674 c$ & $15 / 05 / 2020$ & Asymptomatic & Sahagun & 27/F/yes & Yes & 39.73 & $9.41 \mathrm{E}+01$ \\
\hline $678 c$ & 14/05/2020 & Asymptomatic & Sahagun & 30/F/yes & Yes & 36.63 & $5.49 \mathrm{E}+03$ \\
\hline $682 c$ & $15 / 05 / 2020$ & Asymptomatic & Sahagun & 50/M/yes & Yes & 36.84 & $4.12 \mathrm{E}+03$ \\
\hline $574 d$ & $12 / 05 / 2020$ & Asymptomatic & Monteria & 26/M/no & Yes & 38.51 & $4.52 E+02$ \\
\hline $575 d$ & $12 / 05 / 2020$ & Asymptomatic & Monteria & 17/F/no & Yes & 37.11 & $2.87 \mathrm{E}+03$ \\
\hline 599 & $13 / 05 / 2020$ & Asymptomatic & Monteria & 35/M/no & Yes & 39.39 & $4.57 \mathrm{E}+03$ \\
\hline 600 & $12 / 05 / 2020$ & Asymptomatic & Monteria & 26/M/yes & Yes & 33.66 & $9.54 \mathrm{E}+04$ \\
\hline 601 & $12 / 05 / 2020$ & Asymptomatic & Monteria & 25/M/yes & Yes & 39.08 & $5.75 E+03$ \\
\hline 604 & $12 / 05 / 2020$ & Asymptomatic & Monteria & 61/M/yes & Yes & 36.08 & $9.34 \mathrm{E}+03$ \\
\hline $607 d$ & $13 / 05 / 2020$ & Asymptomatic & Monteria & 17/M/no & Yes & 38.21 & $1.11 \mathrm{E}+04$ \\
\hline $612 d$ & $13 / 05 / 2020$ & Asymptomatic & Monteria & 24/F/no & Yes & 37.67 & $1.68 \mathrm{E}+04$ \\
\hline $613 d$ & $13 / 05 / 2020$ & Asymptomatic & Monteria & 6/F/no & Yes & 35.57 & $2.38 \mathrm{E}+04$ \\
\hline
\end{tabular}

Fe fever, Co cough, $A r$ arthralgia, Od odynophagia, $M$ male, $F$ female 
(Table 1, Fig. 1C). Nonetheless, the average of RNA copies $8.26 \times 10^{10}$ was lower than the average of the symptomatic group. The Wilcoxon test for independent samples showed that there is no significant difference $(p>0.05)$ between the viral RNA copy number of symptomatic and asymptomatic patients (Fig. 1B). Nine of 17 individuals were from Monteria, the remaining nine from Sahagun. Forty-three of the health staff were infected, an important issue because they are in the front line facing the pandemic (Table 1).

On the other hand, 18/35 (51\%) individuals were asymptomatic. All of them had a known infected contact (Table 1); the figure shows the number of infected contacts (Fig. 1C). We do not know whether asymptomatic individuals in the present study developed COVID-19 disease after taking the sample. Of the asymptomatic individuals, 10/18 (56\%) were female, the average age was 30 (range, 6-61 years. Most studies report that males are more affected by coronaviruses than females; however, in the present study, women were more affected than men (53\% symptomatic and 56\% asymptomatic). This trend, $52.31 \%$, continues throughout Cordoba's department and is opposed to national behavior (49.5\%) [2]. Our study has some weaknesses, such as a small sample of individuals and a non-follow-up change from presymptomatic to symptomatic. However, the present study reinforces the concern about the public health implications of asymptomatic/presymptomatic SARS-CoV-2 infection [3-8]. Our results show a $51 \%$ of asymptomatic infected individuals, of which $78 \%(14 / 18)$ presented a considerably high viral copy number, even higher than several symptomatic patients (Fig. 1C). Moreover, RT-PCR Ct values lower than 34 of some them indicate a higher viral load than some symptomatic patients and presumes the possibility to isolate infectious SARS-CoV-2 to demonstrate viral viability $[3,6,8,9]$.

\section{Conclusion}

Since a considerable percentage of infections may be asymptomatic, increased testing approaches may be needed to detect these persons $[10,11]$. Because a large proportion of infections may result from transmission originated in asymptomatic or pre-symptomatic persons, the usefulness of public health interventions in Colombian departments should be based on two steps: a molecular screening in a vast conglomerate's population, and viral load quantification. Finally, a remarkable issue in our study is the fact of young age in symptomatic and asymptomatic individuals (average of 43 years and 30 years, respectively); age group data is essential because the coronavirus pandemic has produced a high impact in the economy and it is probably the cause of the reduced lethality observed in the country and the department at the time of this study.

\section{Acknowledgements}

To MINCIENCIAS and the Rectory of the University of Cordoba for their determined commitment to face coronavirus's pandemic and the financial support. To Paola Diaz for the elaboration of the Figure.

\section{Authors' contributions}

All authors contributed equally to the manuscript's concept, design of the study, collection, analysis, and interpretation of the data. Besides, all authors did review the paper, before submit it. All authors read and approved the final manuscript.

\section{Funding}

The University of Cordoba supported this study.

\section{Availability of data and materials}

Our results are preliminary, and we do not wish to share this preliminary data for the moment.

\section{Ethics approval and consent to participate}

The study follows the ethical standards of the Ministry of Health of Colombia Resolution No. 8430 of 1993. The data of the present study correspond to patients coded under strict anonymity with an internal laboratory number. This study is the results of a research project that was approved by the Comite de ética del Instituto de Investigaciones Biológicas del Trópico de la Universidad de Cordoba, with the No. 0410-2020.

\section{Competing interests}

The authors declare that they have no competing interests.

\section{Author details}

${ }^{1}$ Instituto de Investigaciones Biológicas del Trópico, Facultad de Medicina Veterinaria y Zootecnia, Universidad de Córdoba, Montería, Colombia. ${ }^{2}$ Asociación Colombiana de Infectología, Carrera 15 No. 118-03, Bogotá, Colombia. ${ }^{3}$ University of Cartagena, ALZAK Foundation, Cartagena, Colombia. ${ }^{4}$ Instituto Nacional de Salud, Bogotá, Colombia. ${ }^{5}$ Intensive Care Unite, Clinica Zayma, Montería, Córdoba, Colombia.

Received: 9 August 2020 Accepted: 12 November 2020

Published online: 07 December 2020

\section{References}

1. Worldometers. 2020. https://www.worldometers.info/coronaviru s/\#countries. Accessed 18 Oct 2020.

2. Instituto Nacional de Salud de Colombia. https://www.ins.gov.co/Notic ias/Paginas/Coronavirus.aspx. Accessed 18 Oct 2020.

3. OPS. Actualización situación COVID-19 Colombia, 14 de octubre. https ://www.paho.org/es/documentos/reporte-situacion-covid-19-colom bia-no-159-14-octubre-2020.

4. Dabiao Ch, Wenxiong $X$, Ziying $L$, Zhanlian $H$, Jing $L$, Zhiliang $G$, et al. Recurrence of positive SARS-COV-2 RNA in COVID-19: a case report. Int J Infect Dis. 2020;93:297-9.

5. Furukawa NW, Brooks JT, Sobel J. Evidence supporting transmission of severe acute respiratory syndrome coronavirus 2 while pre symptomatic or asymptomatic. Emerg Infect Dis. 2020. https://doi.org/10.3201/eid26 07.201595.

6. Michael RT, Mina MJ. To interpret the SARS-CoV-2 test, consider the cycle threshold value. Clin Infect Dis. 2020. https://doi.org/10.1093/cid/ciaa619.

7. Sethuraman N, Jeremiah SS, Ryo A. Interpreting diagnostic tests for SARS-CoV-2. JAMA. 2020;323(22):2249-51. https://doi.org/10.1001/ jama.2020.8259.

8. Liu Y, Yan LM, Wan L, Xiang TX, Le A, Liu JM, et al. Viral dynamics in mild and severe cases of COVID-19. Lancet Infect Dis. 2020;20(6):656-7. https ://doi.org/10.1016/S1473-3099(20)30232-2. 
9. Eun S, Seong H, Yu Y, Un S, Kim S. Viral kinetics of SARS-CoV-2 in asymptomatic carriers and presymptomatic patients. Int J Infect Dis 2020:95:441-3.

10. Sun J, Xiao J, Sun R, Tang X, Liang C, Lin H, et al. Prolonged persistence of SARS-CoV-2 RNA in body fluids. Emerg Infect Dis. 2020. https://doi. org/10.3201/eid2608.201097.

11. Wajnberg A, Mansour M, Leven E, Bouvier NM, Patel G, Firpo A, et al Humoral immune response and prolonged PCR positivity in a cohort of
1343 SARS-CoV 2 patients in the New York City region. medRxiv. 2020. https://doi.org/10.1101/2020.04.30.20085613.

\section{Publisher's Note}

Springer Nature remains neutral with regard to jurisdictional claims in published maps and institutional affiliations.
Ready to submit your research? Choose BMC and benefit from:

- fast, convenient online submission

- thorough peer review by experienced researchers in your field

- rapid publication on acceptance

- support for research data, including large and complex data types

- gold Open Access which fosters wider collaboration and increased citations

- maximum visibility for your research: over $100 \mathrm{M}$ website views per year

At BMC, research is always in progress.

Learn more biomedcentral.com/submissions 